\title{
Health Promotion Media To Behavior Change On Exclusive Breastfeeding Mothers
}

\author{
Sudarwati Nababan"1), Epina Yikwa ${ }^{2)}$, Bagoes Widjanarko ${ }^{3)}$ \\ ${ }^{1}$ Nusa Nipa University, Department of Nursing, Faculty of Health Science, Maumere \\ ${ }^{2,3}$ Diponegoro University, Master Program of Health Promotion, Faculty of Public Health, Semarang \\ Email: sudarwatinababan.unipamaumere@gmail.com
}

\begin{abstract}
Background: Exclusive breastfeeding is a process of giving only breast milk to babies since they are born until they are six month old. Membramo Public Health Office reported that according to the health profile report from Kobakma Public Health Centre, the exclusive breastfeeding program has not achieved the national target, which is $80 \%$, only $55,4 \%$ babies who got exclusive breastfeeding in 2015. The chairperson from Kobakma Public Health Centre states that one of the problem is the misunderstanding about breastmilk among mothers in the surroundin. They throw their breast milk away and feed their babies with formulated milk during the period of postpartum for three months. Purpose: This study is aimed to know the effect of counseling program using two sided flipchart on exclusive breastfeeding. Methods: This study uses quasi experiment method with non equivalent control group. The samples of this study are mothers who have 0-6 month old babies and live in working area of Kobakma Public Health. 60 mothers are selected using purposive sampling technique. The Instrument of this study uses questionnaire, data ccollection was done by face to face method. The data was then analyzed using chi square and wilcoxon signed rank test. Results: The result of this study shows significant difference in the improvement of knowledge, behaviour, and practice before and after the counseling program of the intervention group $(p=0,000)$. Conclusion: The implementation of counseling program using two sided flipcharts is effective to improve mothers' knowledge, behaviour and practice in exclusive breastfeeding.
\end{abstract}

Keyword: exclusive breastfeeding, knowledge, practice, two sided flipcharts

\section{INTRODUCTION}

Exclusive breastfeeding is a process of giving only breast milk to babies since they are born until they are six months, except when the babies are sick, in this case they need medication. Breast milk has a substance called antibody which can enhance the immune system and keep the baby digestive system healthy (Kristiyanasari, 2011). WHO recommends mothers to apply Early Initiation of breastfeeding or IMD (Inisiasi Menyusu Dini), exclusive breastfeeding, and breastfeed activity to babies until they are 2 years old. It is based on the fact that breast milk has nutrient and supplies energy as much as the half of nutrient and energy demand needed by 6 11 month old babies and as much as a quarter of 1-2 year old toddlers' nutrient and energy demand (Saputra, 2016).
General Directorate of Public Health explained the pressmen about the IMD program to new born babies have only achieved as much as $51,8 \%$ and exclusive breastfeeding have achieved $54 \%$ of the target during the commemoration of the breast milk week 2017 (Direktorat Jenderal Kesehatan Masyarakat, 2017).

Low target achievement of IMD and breast milk in 2016 shows that there is a challenge that has to be overcome, it is the external factor, which is the lack of support from the health workers, family members, especially husbands, sociocultural factors that do not support exclusive breastfeeding and the work environments which do not facilitate nurseries for mothers to pump out breast milk nor refrigerators to keep the breast milk as well as the never ending promotion and advertising of the 
formulated milk (Kementerian Kesehatan Republik Indonesia, 2016).

Based on national Riskesdas 2013 the achievement of exclusive breastfeeding and breastfeed activity to babies is only $34,5 \%$ from the national target. The lowest achievement is in Maluku province, it is only $25,2 \%$ and in Papua is $31,5 \%$ on the contrary giving formulated milk to babies is drastically increasing from $10,3 \%$ to $32,5 \%$ (Kementerian Kesehatan Republik Indonesia, 2013).

As many as 1248 babies were registered in Middle Mamberamo District, Papua Province in 2014, but only $24,1 \%$ of them who get exclusive breastfeeding (Dinas kesehatan provinsi papua, 2015). The implementation of exclusive breastfeeding in the working area of Kobakma Public Health Centre in 2015 was as much as $55,4 \%$ and increases to be as much as $60 \%$ in 2016, yet the achievement is under the national target which is $80 \%$ (Dinas Kesehatan Kabupaten Mamberamo, 2016).

A study (Maulida, 2017) concluded that a counseling program using flipchart is effective towards the practice of giving breast milk by the postpartum mothers. The mean score of mothers who practice breastfeeding from the intervention group is $(18,43)$ higher than those from the control group $(15,14)$. The difference of the study above from this study are dependent variable, control variable, population, intervention process, and the improvement of the media. The independent variable is breastfeeding practice by postpartum mothers, and the control variables are age, education and socio-economic condition, the counseling is given once for 30 minutes and the post test was held a week after the counseling. Two sided flipcharts are composed through expert judgement process from 3 persons and the material is based on the book of standard counselor module in breast milk by WHO 2011.

A study (Akram, Agboatwalla and Shamsael, 1997) proves that health messages presented in the form of flipchart with photographs of mothers doing breastfeeding in different position, is effective to improve mothers' knowledge and practice in Early Initiation of Breastfeeding and exclusive breastfeeding. The differences between the above study and this study are the location and the time of the study, population and the intervention process. A study conducted in Pakistan by Akram et all, with the population of pregnant mothers, the health education uses counseling method and group discussion, health presentation is held every week for 6 month, while posttest was done after 11 months.

The aim of this study is to identifying the effect of counseling program using two sided flipcharts on implementing exclusive breasfeeding towards the practice of exclusive breastfeeding to 0-6 month old babies in the working area of Kobakma Public Health Centre in the Middle Mamberamo District, Papua Province.

\section{METHODS}

This study used quasi experiment method with non-equivalent control group. It was conducted in the working area of Kobakma Public Health Centre. This study was held in June to July 2018. The population of this study were mothers who have 0-6 month old babies, registered at integrated health service post (Posyandu) who were according to criteria. Those who met inclusion criteria area are mothers who graduated from SD, SMP and SMA, age 18-40 years. While in the exclusion criteria are mothers whose husbands work as medical professionals, and those who work as health cadres. The population is 65 mothers, the sample is 60 respondents divided into 2 groups. The intervention group consists of mothers from Posyandu Kobakma 1 and the control group consists of mothers from Posyandu Kobakma 2. The sample uses purposive sampling technique, mothers from Kobakma 1 was chosen as the intervention group, because the Posyandu has the lowest percentage achievement of exclusive breastfeeding program within the last 6 months. The independent variable of this study is health counseling program using two sided flipcharts, while the dependent variables are: knowledge, behaviour and practice. The controlled variables are age, education, occupation and information from the third party.

The process of developing the health promotion media was initiated through educational study at Public Health Centre Kobakma by conducting focus group discussion with 10 mothers 
during the period of breastfeeding to be the prospective respondents. The selection was based on accidental sampling technique towards mothers who were attending to the Public Health Centre at the time of survey. From the discussion they came to a conclusion of suggestion which enable the participants to be active during the lecture, question and answer session through two sided flipcharts.

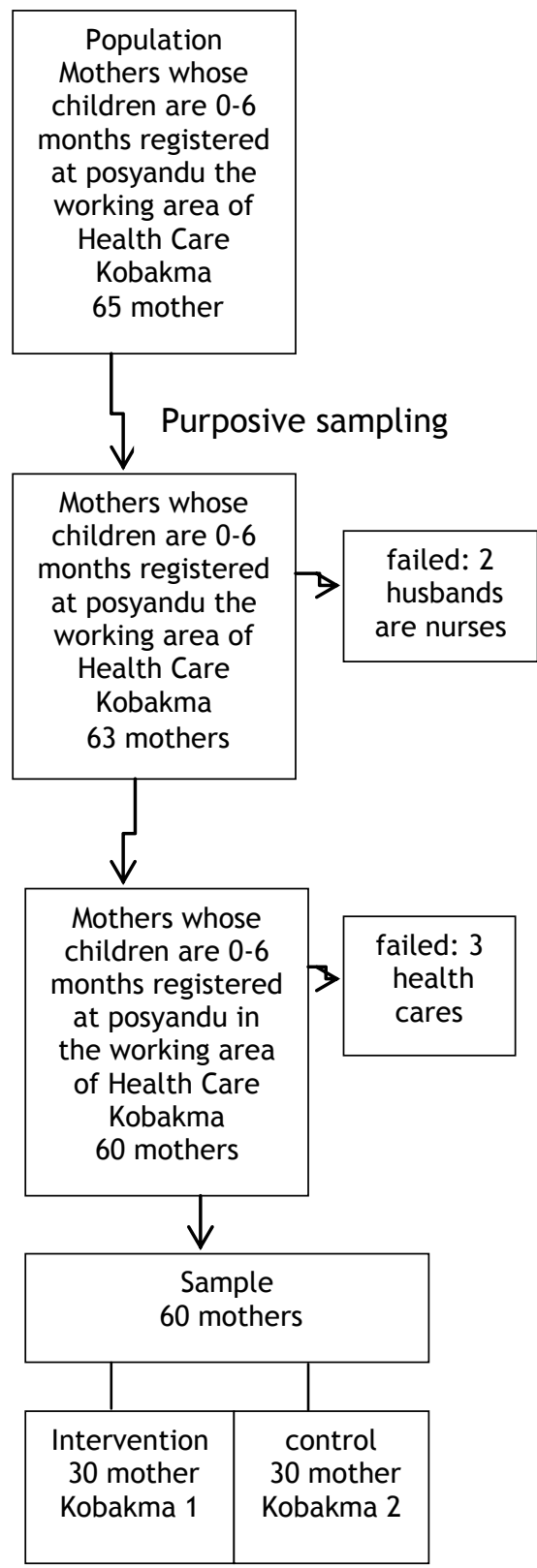

Figure 1. Flowchart of Participants

This educational study was followed up by consultation forum with the chairperson of Kobakma Public Heatlh Centre, 3 village midwives, 2 village chiefs in the working area of Kobakma 1 tribal chief, and 4 health cadres. They were selected to be participants of discussion because they were considered as the role models and they know that their community needs to learn more about the importance of exclussive breastfeeding. They discussed about the plan on on the counseling program (purpose of the counseling, achievable target, infrastructure, time, and place of the counseling as adviced by mothers during thier breastfeeding period).

The two sided flipcharts used in this study is adapted from the previous ones and modified according to the advice from mothers during FGD. The size of two sided flipcharts to be taken home by participants (mothers) is $30 \mathrm{~cm} \times 25 \mathrm{~cm}$, while the size of one used by researcher during the counseling program is $50 \mathrm{~cm} x$ $75 \mathrm{~cm}$. The two sided flipcharts is a page of book consists of 2 pages, except breastfeeding procedures consists of 4 pages, so there are 22 pages as a whole. The material of 10 topics are what exclusive breastfeeding is, the formula of breast milk, the benefits of breast milk, how to implement exclusive breastfeeding, how to pump the breast milk, how to keep and give the breast milk to babies, as well as how to clean and sanitize breast milk wares.

Table 1. Material of Counseling

\begin{tabular}{cc}
\hline Day & \multicolumn{1}{c}{ Material } \\
\hline 1 & 1. What is exclusive \\
& breastfeeding \& the formula \\
& of breast milk? \\
& 2. The benefits of breast milk \\
& \& breastfeeding \\
& 3. How to implement exclusive \\
& breastfeeding? \\
2 & 4. The right procedures of \\
& breastfeeding \\
& 5. The sign that a babyhas \\
& adequate breast milk \\
& 6. How to increase the \\
& production of breast milk? \\
& 7. How to resolve the obstacle \\
& of breastfeeding? \\
& 8. How to pump breast milk? \\
9. How to keep \& and give & breast milk to babies? \\
10. How to clean and sanitize \\
breast milk wares?
\end{tabular}

The instrument used in this study was questionnaire. The data was 
collected using face to face method. Both of study groups were given pretest before the intervention and they were given posttest a month after the intervention, it is on July $23^{\text {rd }} 2018$.

The counseling is held once a week in three times of meeting for $3 \times 90$ minutes using lecture method, with question and answer session. Two sided flipcharts were distributed to the participants before the lecture. The counseling program is held in lady meeting room, the participants have an opportunity to ask questions, evaluation of asking 5 questions.

The data of this study was analyzed using chi square, Mann Withney, and wilcoxon signed rank test mean level 95\% $(a=0,05)$ and this study had been approved by Health Research Ethics Comission, Public Health Facultty, Universitas Diponegoro with the certificate of ethical clearance No. 120/EC/FKM/2018.

\section{RESULT AND DISCUSSION}

The researcher had an interview survey with the chairperson of Public Health Centre in the beginning of May 2018, it is concluded that the problem which inhibits the practice of giving exclusive breastfeeding in the working area of Kobakma Public Health Centre is that mothers' misunderstanding about breastfeeding, this problem is the same as found in Papua general. The community considers that colostrum is stale breast milk so there is a habit that every single postpartum mother throws away her colostrum by pumping out her breast milk. When breast milk does not come out at the same time as the time of delivery, so the mother or the father is considered to be under the curse so the breast milk has to be squeezed out using warm stones. The treatment to a newborn baby is handled by a medicaster by giving the baby strong coffee in order to discharge impurities which are swollen while the baby is in the womb. Medicaster like to give newborn babies unripe coconut water, juice of the extraction from Terminalia copelandii elmer leaves, and papeda liquid (a kind of food made of sago plantation from Papua) as a substitution of breast milk when the mother does not supply adequate breast milk during postpartum care. Mothers feed their babies after 3 months with mashed up sago, banana and cassava in order to make their body strong and prevent them from crying (Yufuai and Widagdo, 2013)

Babies in Middle Mamberamo District rarely get adequate breast milk because mothers leave their babies at home while working in the field far away from home. There is lack of support from health workers dealing with exclusive breastfeeding program in Middle Mambremo District, besides the location of Public Health Centre is far from residential areas. The health workers can only counsel orally to families who come to the Public Health Centre without any counseling media (Dinas Kesehatan Kabupaten Mamberamo, 2016)

Flipchart is a media to convey a kind of health message in two sided page. There are pictures to display on one page, and there is the related information on the other side of the page. The advantage of two sided flipchart is to make it easier for the health workers to describe to the counselee, while showing the pictures that can be noticed by the counselee, it is interesting and easy to understand. The minimum size of two sided flipchart is 21 $\mathrm{cm} \times 28 \mathrm{~cm}$ and the maximum size is 50 $\mathrm{cm} \times 75 \mathrm{~cm}$, the printed letters have to be easily visible and readable within a distance of 6 meters with the maximum of 6 sentences or 25 words on one page (Waryana, 2016).

The improvement of media in health promotion as the researcher shows first series of two sided sheet on breastfeeding developed by a team from Direktorat Jenderal Bina Kesehatan Masyarakat Kementerian Republik Indonesia and UNICEF in 2010. The researcher has a discussion with 10 mothers on the two sided flipchart whether the message is easy to understand as it would be used as a health counseling media. From the FGD they came to a conclusion that the two sided flipchart has to be modified so that the choice of word is easy to understand by the local community, so they use Papuans' dialect instead of standard Bahasa and the pictures of mother who is breastfeeding were replaced with a mother from the Papuan ethnic group. The words which are replaced are:

a. Ibu (mother) replaced with 'mama' 
b. Tidak memberikan makan (do not feed) replaced with 'tra kasi makan'

c. Menyusui (breastfeeding) replaced with 'kasi susu'

d. Dengan nyaman kita (we comfortably) replaced with 'deng nyaman kitorang'

e. Meninggalkan anak (leaving the children) replaced with 'kastinggal anak'

The characteristics of mothers from both intervention and control groups before the intervention is equal, $p>0,05$ (table 2). There is no significant differences in the level of knowledge, behaviour and practice of mothers from intervention and control groups according to pretest $p>0,05$ (table 3 ).

The result of pre-test is to make sure that both characteristics of respondents from intervention and control groups have the same condition at the beginning. It is to prove that the different mean scores of knowledge, behaviour, and practice from the post-test shows that the intervention of counseling program using two sided flipcharts is effective.

Table 4 shows that there is a significant mean difference on knowledge, behaviour, and practice between pre-test and post-test from the intervention group, $p<0,05$. There is a significant mean difference on knowledge from control group, $p=0,005$. There is no mean difference on behaviour and practice between pre-test and post-test from control group $\mathrm{p}>0,05$.

Table 2. Characteristic Distribution of Mothers in Working Area of Kobakma Public Health Centre, June 2018 using Chi Square Test

\begin{tabular}{|c|c|c|c|c|c|}
\hline \multirow{2}{*}{ Characteristics } & \multicolumn{2}{|c|}{ Intervention } & \multicolumn{2}{|c|}{ Control } & \multirow{2}{*}{$P$ Value } \\
\hline & Frequency & $\%$ & Frequency & $\%$ & \\
\hline \multicolumn{6}{|c|}{ Age } \\
\hline$<25$ years & 2 & 6,7 & 6 & 20 & \multirow{2}{*}{0,625} \\
\hline$>25$ years & 28 & 93,3 & 24 & 80 & \\
\hline Total & 30 & 100 & 30 & 100 & \\
\hline \multicolumn{6}{|l|}{ Education } \\
\hline Illiterate/SD & 11 & 36,7 & 10 & 33,3 & \multirow{3}{*}{0,128} \\
\hline SMP & 2 & 6,7 & 2 & 6,7 & \\
\hline SMA & 17 & 56,7 & 18 & 60 & \\
\hline Total & 30 & 100 & 30 & 100 & \\
\hline \multicolumn{6}{|l|}{ Occupation } \\
\hline House wife & 16 & 53,5 & 13 & 43,3 & \multirow{3}{*}{0,380} \\
\hline Non Civil Servant & 5 & 16,7 & 5 & 16,7 & \\
\hline Civil Servant & 9 & 30 & 12 & 40 & \\
\hline Total & 30 & 100 & 30 & 100 & \\
\hline \multicolumn{6}{|c|}{ Information on Exclussive Breastfeeding } \\
\hline Yes & 13 & 43,3 & 11 & 36,7 & \multirow{2}{*}{0,384} \\
\hline No & 17 & 56,7 & 19 & 63,3 & \\
\hline Total & 30 & 100 & 30 & 100 & \\
\hline
\end{tabular}

Table 3. Pre-test result of Comparison of mothers' Knowledge, Behaviour and Practice from Intervention and Control Groups using Mann Whitney Test

\begin{tabular}{lccccccc}
\hline \multirow{2}{*}{ Variable } & \multicolumn{3}{c}{ Intervention } & \multicolumn{3}{c}{ Control } & \multirow{2}{*}{ P Value } \\
\cline { 2 - 7 } & Mean & \pm SD & Median & Mean & \pm SD & Median & \\
\hline Knowledge Pretest & 8,30 & 2,103 & 8 & 8,27 & 1,617 & 8 & 0,2 \\
Attitude Pretest & 5,27 & 1,311 & 5 & 5,23 & 1,357 & 5 & 0,122 \\
Practice Pretest & 2,97 & 0,99 & 3 & 2,90 & 0,662 & 3 & 0,104 \\
\hline
\end{tabular}

The increasing of mean value on knowledge from the intervention group after the counseling program is as many as 10,8 poin, $p$ value 0,000 . The improvement of respondents' knowledge from the intervention group is because of health counseling was done once a week, there times of meetings. This is based on the purpose of health counseling program to improve knowledge and to educate the community to be aware of health conditions (Notoatmodjo, 2012). Laurence Green theory emphasizes on the importance of health education as one of interventions related to changing in predisposing factor which are knowledge and behaviour (Waryana, 2016). This study is similar to (Purba, 2017) study 
that explains the importance of counseling program about exclusive breastfeeding towards pregnant mothers' knowledge and behaviour due to one of the factors which influences the level of knowledge as the source of information they get from counseling program using two sided flipcharts (Sari, Wulandari and Hidayat, 2018) in their study also concludes that there is a difference in mothers' knowledge before and after a counseling program about exclusive breastfeeding.
The increasing mean value on behaviour from the intervention group after the counseling program is 7,1 point with $p$ value 0,000 . Behaviour is expressed by a person who responds a stimulus after utilizing mind, feeling and attention (Notoatmodjo, 2012). In this study, after the participants understand the lecture, they respond by expressing agreement behaviour towards the health advice, that is to breastfeed a baby as soon as the baby is born, to give exclusive breastfeeding and continue to breastfeed until the baby is 2 years.

Table 4. Comparison of Mothers' Knowledge, Behaviour, and Practice Before and After the Counseling Program with Two Sided Flipcharts using Wilcoxon Signed Rank Test

\begin{tabular}{|c|c|c|c|c|c|}
\hline \multirow{2}{*}{ Group } & \multicolumn{2}{|c|}{ Pre-Test } & \multicolumn{2}{|c|}{ Post-test } & \multirow{2}{*}{ P Value } \\
\hline & Mean & \pm SD & Mean & \pm SD & \\
\hline \multicolumn{6}{|c|}{ Knowledge } \\
\hline Intervention & 8,30 & $\pm 2,103$ & 19,10 & $\pm 2,006$ & 0,000 \\
\hline Control & 8,27 & $\pm 1,617$ & 9,67 & $\pm 1,863$ & 0,005 \\
\hline \multicolumn{6}{|l|}{ Behaviour } \\
\hline Intervention & 5,27 & $\pm 1,311$ & 12,33 & $\pm 1,184$ & 0,000 \\
\hline Control & 5,23 & $\pm 1,357$ & 4,80 & $\pm 1,095$ & 0,192 \\
\hline \multicolumn{6}{|l|}{ Practice } \\
\hline Intervention & 2,97 & $\pm 0,99$ & 8,50 & $\pm 0,900$ & 0,000 \\
\hline Control & 2,90 & $\pm 0,662$ & 3,47 & $\pm 0,937$ & 0,016 \\
\hline
\end{tabular}

This study is paralel with the study of (Merdhika, Mardji and Devi, 2014) which proves that there is an effect of counseling program towards the level of mothers' knowledge and behaviour in exclusive breastfeeding (Saleh et al., 2011) in their study of counseling program using modelling approach also proves that counseling program conducted by nurses is effective to increase mothers' self-confident behaviour to breastfeed their babies.

The increasing of mean value in practice from the intervention group after the counseling program is 5,5 point with $p$ value 0,000 . The difference of mean value statistically is enhanced by the researcher's supervision. After having a counseling program for 1 month mothers in the area of Posyandu Kobakma 1 realize the importance of breastfeeding, before going to the field, mothers pump the breast milk and ask for a help from their family members who take care of their babies to give them the breast milk.

The result of this study is the same as the study conducted before entitled "The role of two sided media to increase mothers' behaviour towards their children's healthy teeth and mouths" (Rachmawati, Darwita and Setiawati,
2012). The result of the study proves that health counseling program using two sided media is effective to improve mothers' behaviour attending to Posyandu to keep their children's healthy teeth and mouths, especially in brushing teeth activity

Other research concludes that health counseling program using two sided media is effective to improve working mothers' behaviour in breastfeeding (Marifah and Ika, 2016). The flipcharts used in counseling program of this study use interesting illustrations, so that the participants are willing to practice the right techniques of breastfeeding, the procedures of pumping and keeping breast milk.

\section{COCLUSION}

Health counseling program about exclusive breastfeeding is effective to improve mothers' knowledge, behaviour, and practice in the working area of Kobakma Public Health Centre Middle Mamberamo District, Papua Province. It can be proven by the mean score of posttest from the intervention group which is higher than the mean score of post-test from control group. As a suggestion to the management of Kobakma Public Health 
Centre, the implementation of counseling program using two sided media in Papuan dialect can be an alternative effort to improve practice in exclusive breastfeeding.

\section{REFERENCES}

Akram, D. S., Agboatwalla, M. and Shamsael, S. (1997) 'Effect of Intervention on Promotion of Exclusive Breast Feeding', Pakistan medical Association, 47, pp. 46-48.

Dinas Kesehatan Kabupaten Mamberamo (2016) 'Profil Kesehatan Kabupaten Mamberamo Tengah'.

Dinas kesehatan provinsi papua (2015) 'Profil Kesehatan Provinsi Papua'.

Direktorat Jenderal Kesehatan Masyarakat (2017) 'Meningkatkan Asi Eksklusif masih Menjadi Tantangan'. Jakarta: Kementerian Kesehatan RI.

Kementerian Kesehatan Republik Indonesia (2013) Laporan Hasil Riset Kesehatan Dasar (Riskesdas) Indonesia. Jakarta: Badan Penelitian dan Pengembangan Kesehatan. doi: 1 Desember 2013.

Kementerian Kesehatan Republik Indonesia (2016) 'Beri ASI Sampai 2 Tahun untuk Wujudkan Keluarga Sehat'.

Kristiyanasari, W. (2011) ASI Menyusui dan Sadari. Yogyakarta: Nuha Medika.

Marifah, U. and lka, R. (2016) 'Pengaruh Pendidikan Kesehatan dengan Media Flip Chart Terhadap Perilaku Pemberian ASI Pekerja Wanita di Puskesmas Sidotopo Wetan', Health Sciences, 8(2), pp. 1-9.

Maulida, L. fajria (2017) 'Pengaruh Pendidikan Kesehatan dengan Lembar Balik Terhadap Perilaku Pemberian ASI pada Post Partum', Kebidanan Midwiferia, 3(2), pp. 40-56.

Merdhika, W. A. R., Mardji and Devi, M. (2014) 'Pengaruh Penyuluhan ASI Eksklusif Terhadap Pengethuan
Ibu Tentang ASI Eksklusif dan Sikap Ibu Menyusui di Kecamatan Kanigoro Blitar', Teknologi dan Kejujuran, 37(1), pp. 65-72.

Notoatmodjo, S. (2012) Promosi Kesehatan dan Perilaku Kesehatan. Jakarta: Rineka Cipta.

Purba, I. P. S. (2017) 'Pengaruh Penyuluhan ASI Eksklusif Terhadap Pengetahuan dan Sikap Ibu Hamil di Kelurahan Alur Dua Kecamatan Sei Lepan', Skripsi Universitas Sumatera Utara.

Rachmawati, M., Darwita, R. R. and Setiawati, F. (2012) 'Peran Media Lembar Balik dalam Meningkatkan Perilaku Ibu terhadap Kesehatan Gigi \& Mulut Anak dan Evaluasi dengan KMGS'. Perpustakaan Universitas Indonesia, FKG UI.

Saleh, A. et al. (2011) 'Pengaruh Pendidikan Kesehatan Dengan Pendekatan Modelling Terhadap Pengetahuan, Kemampuan Praktek dan Percaya Diri Ibu dalam Menstimulasi Tumbuh Kembang Bayi 0-6 Bulan Di Kabupaten Maros', Jurnal Ners, 6(2), pp. 1-22.

Saputra, Y. (2016) 'Pekan ASI Sedunia: Angka Pemberian ASI di Indonesia Masih Rendah'.

Sari, T. W., Wulandari, F. S. and Hidayat, M. H. (2018) 'Perbedaan Pengetahuan ibu Sebelum dan Sesudah diberikan Penyuluhan tentang ASI Eksklusif di Wilayah kerja Puskesmas Sidomulyo Pekan Baru', Collaborative Medical Journal, 1(2), pp. 58-65.

Waryana (2016) Promosi Kesehatan Penyuluhan dan Pemberdayaan Masyarakat. Yogyakarta: Nuha Medika.

Yufuai, A. R. and Widagdo, L. (2013) 'Praktik Budaya Suku Kampung Yepase Terkait Perawatan kehamilan, Nifas, dan Bayi di Distrik Depapre Kabupaten Jayapura', Jurnal Promosi Kesehatan Indonesia, 8(2), pp. 100-110. 